\title{
Optimal Model to Estimate Biomass and Carbon Stock at Agroforestry Stand Cempaka (Elmerillia $\mathrm{Sp})$ in Minahasa District
}

\author{
Yohanes Andreas Robert Langi, Altien Jonatan Rindengan, Charles Eferaim Mongi, \\ Rinancy Tumilaar, Martina Langi
}

\begin{abstract}
Management of stands in community forests such as agroforestry and stands outside forest areas can reduce greenhouse gas emissions. The agroforestry system is a good choices in reducing climate change compared to other options in terrestrial ecosystems. This study aimed at obtaining the most optimal model to estimating the biomass of Cempaka tree (Elmerillia Sp) in community forest stands in Minahasa Regency. The sample was selected through stratified random sampling from two locations. The first location represents the stand of the Cempaka tree community forest, and the second location represents mixed community forest stands. 35 trees were selected for felling, and measurements of wet weight and biomass were carried out based on tree parts. The model to be developed is an allometric regression model of 35 selected trees, and a previously published model. The estimation model obtained is the Cempaka tree biomass estimator model according to tree dimensions such as stems, branches, twigs, leaves, and roots. The results showed that the allometric regression model in the form of logarithmic regression with one independent variable, i.e. diameter of the tree, was quite good in predicting the Cempaka tree biomass. The accuracy of the estimator model for total tree biomass shows $R^{2}$ of $99.5 \%$ with MSE 0.0023 in pure cempaka tree stands. At the second location the coefficient $R^{2}$ is $98.3 \%$ with MSE 0.0038 . The predictive results show that the cempaka tree in the community forest stands has a biomass content of $62 \%-72 \%$, and the stem part is the largest content.
\end{abstract}

Index Terms: Allometric Regression, Biomass, Cempaka Tree, Estimator Model

\section{INTRODUCTION}

Good tree management in social forestry such as agroforestry, private forestry can mitigate greenhouse gas (GHG) emission under the Kyoto Protocol. Agroforestry system is a better option in climate change mitigation than terrestrial option because of the secondary benefits such as helping to attain food security, increasing farm income,

Revised Manuscript Received on April 25, 2019.

Yohanes Andreas Robert Langi, Department of Mathematics, Sam Ratulangi University, 95115, Manado,Indonesia

Altien Jonatan Rindengan, Department of Mathematics, Sam Ratulangi University, 95115, Manado,Indonesia

Charles Eferaim Mongi, Department of Mathematics, Sam Ratulangi University, 95115, Manado,Indonesia

Rinancy Tumilaar, Department of Mathematics, Sam Ratulangi University, 95115, Manado,Indonesia

Martina Langi, Department of Forestry, Sam Ratulangi University, 95115, Manado,Indonesia maintaining above-ground and below-ground, biodiversity, soil conservation [1]; reduce emission [2], and expand forest

Agroforestry is a form of management practice community-based forest. Agroforestry has potential as one large enough carbon sink [3]. More than 345 million ha the area of plantation forest and agroforestry has the potential to be developed for carbon conservation and absorption [4]. This practice will result in absorption carbon at around 6.3-16.4 GtC per year, and give contributions to economic benefits for farmers in the CDM framework. The study also states that more than $50 \%$ carbon forests can be a product of community-based activities [5].

This study aimed at determining the most optimal model based on the relationship among the tree dimensions to estimate the biomass and carbon potential of the Cempaka tree (Elmerillia Sp) by using the allometric regression equation, and determining the allometric relationship between biomass and carbon uptake potency. The model was built based on 35 cempaka trees that were harvested from various diameter and age classes, while the used model was the model that had been previously published.

Research on allometric relations models has been carried out in several types of forests and agroforestry. Estimation of tree biomass has been conducted to predict carbon fluxes [6],[7], and for carbon (C) sequestration on tree parts [8]. Several studies have been developed for several variations of the model of the relationship between tree species biomass in tropical natural forests [9], plantations, and agroforestry [10],[11].

There are two approaches used in Estimation and Measurement of Tree Biomass to estimate tree biomass, i.e. the volume approach and the equation approach [12]. The volume approach is Above-ground biomass $($ ton $/$ ha $)=V O B x$ WD $x$ BEF [13] where:

$V O B=$ Volume of branch-free stems with skin $\left(m^{3} / h a\right)$

$W D=$ Wood density (oven dry biomass) (tons)

$B E F=$ Ratio of total dry tree biomass above-ground with dry biomass of forest inventory.

The equation approach is Above-ground biomass $Y=a D^{b}$ where:

$Y=$ tree biomass $(\mathrm{kg})$

$D=$ diameter at breast height $(130 \mathrm{~cm}), a$ and $b$ are constants.

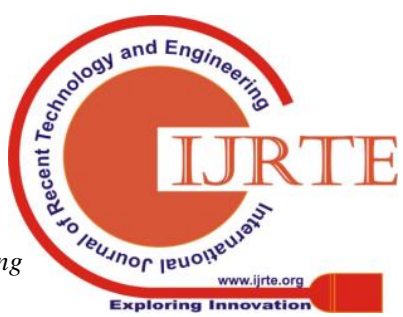




\section{Optimal Model To Estimate Biomass and Carbon Stock at Agroforestry Stand Cempaka (Elmerillia Sp) in Minahasa District}

Some experts develop biomass estimation of allometric relations by building relationships of tree diameter and tree heights [14],[15].

The dimensional analysis ( $d b h$ and height) of a tree has been proven and is able to explain more than $95 \%$ of the variation in tree biomass.

\section{MATERIAL AND METHOD}

The study material was 35 Cempaka trees (Elmerillia $S p$ ) harvested at two locations in Minahasa District, which represented various diameter sizes and tree ages. At the first location, 20 trees were selected which represented the pure stands of Cempaka trees (Elmerillia Sp) in the Cempaka agroforestry stands. In the second location, 15 trees selected which represented mixed agroforestry stands. A total of 35 selected trees were taken from 50 sample plots using stratified random sampling. Diameter $(d b h)$, height $(h)$, basal area $(b a)$, crown area, wet weight $(b b)$ were measured, while measurements in the laboratory included: oven-dried weight and tree density.

\section{A. Description of Cempaka (Elmerillia Sp)}

Cempaka trees are endemic in Minahasa. Two types of Cempaka that can be found in this region are Cempaka (Elmerillia $S p$ ) and Cempaka Wasian (Elmerillia Ovalis Sp). Cempaka trees have moderate growth ability, and widely planted in agroforestry [16]. In natural forests as their habitat, they can have diameter $(d b h)$ of $45-55 \mathrm{~cm}$, branch-free height of 15-20 m, estimate lifespan of 30-40 years, while in the agroforestry area which is developed by farmers, can reach lifespan of 20-30 years, have diameter $(\mathrm{dbh})$ of 40-50 cm, and branch-free height of 10-15 $\mathrm{m}$ [16]. They thrive at around 300-400 meters above sea level, and many are planted in the Minahasa, Tomohon and South Minahasa districts.

\section{B. Statistical Analysis}

The Biomass estimator model used in this model is based on the allometric equation, which is developed from the regression equation model $Y=f(\varsigma, \phi)+\varepsilon$ [17]. The estimation model obtained from this research is intrinsically linear with geometric shape that can be linearized through logarithmic transformations. General form of geometric model $Y=\alpha X^{\beta}$.

Generally, the tree biomass is determined indirectly through allometric equations arranged for tree biomass estimation. Some of allometric equations have been developed by Brown [9], [12],[13] for tree species in tropical forests.

A total of 35 sample trees, especially Elmerrilla sp, were chosen to represent tree species in the agroforestry stand. They are the dominant tree species planted in both agroforestry locations, and in Minahasa generally there are no allometric equations available. These samples then be used to construct biomass allometric estimator equation.

\section{Biomass Estimator Stand Model of Elmerillia sp}

Allometric equation model are constructed from the assumption that there is a significant functional relationship between tree biomass and tree dimension. This relationship is examined using the equation models that was tested previously. The tree dimension used includes allometrics, which considered both one variable dimension and two variable dimension. Allometric equation that typically used in tropical forest are:

$$
\begin{aligned}
& \log Y=\log \alpha+\beta \log D_{i}+\varepsilon_{i} \\
& \log Y=\log \alpha+\beta \log D_{i}+\gamma \log H_{i}+\varepsilon_{i} \\
& Y=\alpha+\beta D+\gamma D^{2} \varepsilon_{i} \\
& \text { Where: } \\
& Y=\text { biomass estimation }(\text { ton } / h a) ; \\
& \alpha, \beta, \gamma=\text { regression parameters } ; \\
& D=\text { Tree's diameter }(D b h)(\mathrm{cm}) ; \\
& H=\text { Tree's Height }(m) ; \\
& \varepsilon_{i}=\text { Error. }
\end{aligned}
$$

Equation (1) is an equation that is widely used by researchers [18]-[20], and it is in line with the requirements of accuracy and practically. Equation (2) is an extension of equation (1) by adding the height of the tree. Equation (3) is the second order polynomial equations as proposed by Brown [12] for allometrics biomass tree in tropical forests.

\section{RESULTS AND DISCUSSION}

Tables 1 and 2 show the description of the Cempaka tree on both locations. Table 1 shows the agroforestry stand dominated by pure Cempaka trees, while in the second table shows the location of mixed agroforestry stand with other trees.

Table 3 presents the model of the chosen allometrics equation and description of statistical criteria testing for the basis of selecting the best regression equation. The best regression equation model is statistically shown by the coefficient of determination $R^{2}$, standard error estimation $(s)$, PRESS Statistic and $F$ Statistic and also the selection criteria for $C V_{d}$ and MSPE models. The best model has to meet the criteria that has the highest value of $R^{2}$ and $F$ Statistic and the lowest value of $s$, PRESS Statistic, $C V_{d}$ and MSPE.

The high of Correlation Value $(r)$ obtained between the totals of tree biomass and tree stem with $D b h$, both types: Wasian and Cempaka. The correlation coefficient $(r)$ between logarithm from Dbh $(\log \mathrm{D})$ and Logarithm from total biomass $(\log \mathrm{Y})$ are $99.2(p<0.05)$ for Wasian type and $99.7(p<0.05)$ for Cempaka, and between the logarithm from Dbh and logarithm from stem's biomass (Log Biostem) are $98.4(p<0.05)$ for Wasian, and $99.8(p<0.05)$ for Cempaka. Table 13 shows that based on the selection of the best regression parameter models to estimate the totals of tree biomass and part of tree trunk biomass and also other part of tree network which, the equations with one independent variable, i.e. tree diameter, are statistically very significant. This can be seen from the value of coefficient of 
determination $R^{2}: 99.2$ and $98.4(p<0.05)$ for Wasian type, while for Cempaka $R^{2}$ is $99.7 \%$ and $99.8 \%(p<0.05)$. Also, other statistical indicators such as standard error $(s)$, Press Statistic, MSPE and $C V_{d}$ are very small and the highest value are $R^{2}$ and $F$ Statistic.

The equation for tree biomass estimation using tree diameter variable is sufficiently reliable to estimate tree biomass. Equation 1 with tree diameter as an estimator variable provides high accuracy compared to equation 2 which includes two estimator variables

(tree diameter and height). The addition of tree height variable statistically only causes little diversity and tends to be unreal $(p<0.05)$ in increasing accuracy of tree biomass estimation. This is reflected by the value of $R^{2}$ which tends to be fixed (or only increases slightly) or even tends to decrease. On equation 3 , the 2 nd order polynomial model with the combination of $\mathrm{D}$ and $\mathrm{D}^{2}$ as independent variables, the result is statistically good enough with very high $R^{2}$ values, but the value of $s, P R E S S, M S P E$ and $C V_{d}$ are very large. However, $\mathrm{F}$ statistics $(p<0.05)$ tend not to be significantly different or insignificant and this model is not consistent as a biomass estimator for other parts of the tree network.

Table 1. Descriptive statistics of 20 tree samples used developing regression allometric biomass model at agroforestry tree cempaka (Elmerrilia $S p$ ) (location which is dominated by cempaka trees)

\begin{tabular}{|c|c|c|c|c|}
\hline Tree Dimension & Range & Mean & Se & MSe \\
\hline Diameter dbh $(\mathrm{cm})$ & $20.50-45.25$ & 36.26 & 9.25 & 2.64 \\
\hline Total High $(\mathrm{m})$ & $23.50-36.25$ & 26.10 & 8.54 & 2.28 \\
\hline High branch free $(\mathrm{m})$ & $14.50-26.20$ & 13.15 & 4.86 & 1.32 \\
\hline Canopy $\left(\mathrm{m}^{2}\right)$ & $10.5-13.0$ & 58.0 & 49.3 & 11.5 \\
\hline Age (year) & $10.00-30.00$ & 15.88 & 5.5 & 2.1 \\
\hline Basal Area $\left(\mathrm{m}^{2}\right)$ & $328.99-1607.34$ & $\begin{array}{c}1146.5 \\
0\end{array}$ & 64.8 & 7.42 \\
\hline Stem Biomass $(\mathrm{kg})$ & $76.2-1565.1$ & 446.7 & $\begin{array}{c}233 . \\
7\end{array}$ & 50.3 \\
\hline Branch Biomass $(\mathrm{kg})$ & $32.5-309.1$ & 66.5 & 46.6 & 26.6 \\
\hline Twigs Biomass $(\mathrm{kg})$ & $0.98-89.02$ & 22.50 & $\begin{array}{c}25.8 \\
5\end{array}$ & 6.67 \\
\hline Leave Biomass $(\mathrm{kg})$ & $2.59-49.34$ & 20.46 & $\begin{array}{c}14.3 \\
2\end{array}$ & 3.70 \\
\hline Fruits Biomassa $(\mathrm{kg})$ & $0.00-10.75$ & 1.53 & 1.90 & 1.01 \\
\hline Bark Biomass $(\mathrm{kg})$ & $10.86-83.20$ & 29.04 & $\begin{array}{c}21.9 \\
6\end{array}$ & 6.19 \\
\hline Root Biomass $(\mathrm{kg})$ & $12.6-65.3$ & 34.1 & 13.0 & 5.7 \\
\hline Total Biomass $(\mathrm{kg})$ & $121.0-2762.0$ & 679.1 & 303 & 94 \\
\hline
\end{tabular}

Table 2. Descriptive statistics of 15 sampled trees used developing regression allometric biomass model at agroforestry tree cempaka (Elmerrilia Sp) (Mix Location Cempaka Tree)

\begin{tabular}{|c|c|c|c|c|}
\hline Tree Dimensi & Range & Mean & Se & MSe \\
\hline Diameter dbh $(\mathrm{cm})$ & $17.50-40.00$ & 21.00 & 10.59 & 3.99 \\
\hline Total High $(\mathrm{m})$ & $16.50-28.55$ & 22.05 & 6.65 & 2.97 \\
\hline High branch free $(\mathrm{m})$ & $12.0-19.01$ & 10.82 & 3.99 & 1.13 \\
\hline Canopy $\left(\mathrm{m}^{2}\right)$ & $6.10-13.20$ & 10.22 & 16.11 & 8.32 \\
\hline Age $($ year $)$ & $15.0-25.0$ & 20.05 & 4.74 & 1.22 \\
\hline Basal Area $\left(\mathrm{m}^{2}\right)$ & $239-1599.4$ & 715.2 & 71.60 & 11.55 \\
\hline Stem Biomass $(\mathrm{kg})$ & $56.3-1330.7$ & 380.5 & 155.8 & 81.9 \\
\hline Branch Biomass $(\mathrm{kg})$ & $31.9-366.9$ & 77.9 & 69.3 & 15.6 \\
\hline Twigs Biomass $(\mathrm{kg})$ & $20.9-273.0$ & 69.6 & 48.5 & 15.7 \\
\hline Leave Biomass $(\mathrm{kg})$ & $11.89-75.69$ & 33.54 & 18.03 & 9.43 \\
\hline Fruits Biomassa $(\mathrm{kg})$ & $0.00-15.42$ & 5.83 & 2.90 & 1.52 \\
\hline
\end{tabular}

\begin{tabular}{|c|c|c|c|c|}
\hline Bark Biomass (kg) & $8.50-198.0$ & 42.9 & 20.5 & 13.0 \\
\hline Root Biomass $(\mathrm{kg})$ & $1.3-30.0$ & 26.8 & 19.1 & 2.4 \\
\hline Total Biomass $(\mathrm{kg})$ & $114.0-2691.0$ & 514.2 & 674.0 & 174 \\
\hline
\end{tabular}

Tabel 3. Estimate Biomass Model Selected Cempaka (Elmerillia Sp)

\begin{tabular}{|c|c|c|c|c|c|c|c|}
\hline Parts & $\begin{array}{c}\text { Equation } \\
(\mathrm{Y})\end{array}$ & $\mathrm{R}^{2}$ & $\mathrm{~s}$ & PRESS & $\mathrm{F}$ & MSPE & $\mathrm{CV}$ \\
\hline & & \multicolumn{3}{|c|}{ First Location } & & & \\
\hline Stem & $0.0971 \mathrm{D}^{3.49}$ & 98.4 & 0.0703 & 0.08935 & 862.86 & 0.124 & 0.0012 \\
\hline Branch & $0.0240 \mathrm{D}^{2.39}$ & 97.5 & 0.0853 & 0.12890 & 543.44 & 0.667 & 0.0654 \\
\hline Twigs & $0.0096 \mathrm{D}^{2.47}$ & 96.4 & 0.1055 & 0.18737 & 376.66 & 0.766 & 0.0466 \\
\hline Leaf & $0.137 \mathrm{D}^{1.63}$ & 89.3 & 0.1245 & 0.29183 & 117.86 & 2.044 & 1.0668 \\
\hline Fruit & $0.0013 \mathrm{D}^{2.49}$ & 74.1 & 0.0547 & 0.05679 & $6.71^{* *}$ & 2.124 & 3.2001 \\
\hline Skin & $0.0081 \mathrm{D}^{2.51}$ & 95.6 & 0.1187 & 0.23706 & 308.1 & 0.881 & 0.6241 \\
\hline Root & $0.0302 \mathrm{D}^{2.29}$ & 95.3 & 0.1123 & 0.22407 & 287.57 & 0.662 & 0.3210 \\
\hline Total & $0.1991 \mathrm{D}^{2.40}$ & 99.2 & 0.0479 & 0.04115 & 1730.72 & 0.225 & 0.0126 \\
\hline & & & \multicolumn{2}{|c|}{ Second Location } & & & \\
\hline Stem & $0.0263 \mathrm{D}^{2.79}$ & 99.8 & 0.0269 & 0.01181 & 8256.96 & 0.027 & 0.0012 \\
\hline Branch & $0.0091 \mathrm{D}^{2.49}$ & 98.1 & 0.0835 & 0.12363 & 730.05 & 0.212 & 0.2011 \\
\hline Twigs & $0.0023 \mathrm{D}^{2.89}$ & 98.1 & 0.0901 & 0.15164 & 736.63 & 0.679 & 0.3144 \\
\hline Leaf & $0.0631 \mathrm{D}^{1.83}$ & 93.6 & 0.1077 & 0.21321 & 206.39 & 1.674 & 1.0960 \\
\hline Fruit & $0.7112 \mathrm{D}^{0.624}$ & 77.2 & 0.0280 & 0.01698 & 7.76 & 4.88 & 6.09 \\
\hline Skin & $0.0021 \mathrm{D}^{2.88}$ & 98.3 & 0.0849 & 0.12203 & 825.02 & 0.114 & 0.0124 \\
\hline Root & $0.1 \mathrm{D}^{2.67}$ & 96.9 & 0.1084 & 0.25823 & 432.75 & 2.680 & 1.2442 \\
\hline Total & $0.0646 \mathrm{D}^{2.71}$ & 99.7 & 0.0331 & 0.01998 & 4795.74 & 0.013 & 0.0012 \\
\hline
\end{tabular}

\section{CONCLUSION}

The allometric equation model with one independent variable that is tree diameter (Dbh) is the best model and is reasonably reliable and consistent in estimating biomass potency and carbon uptake of Cempaka tree in agroforestry. The selected allometric equation model for estimating total biomass of Cempaka tree is $Y=0.0646 \mathrm{D}^{2.71}$ with the coefficient of determination $\left(R^{2}\right)=99.7 \%$, and for Cempaka domination is $Y=0.1991 \mathrm{D}^{2.40}$ with the coefficient of determination $\left(R^{2}\right)=99.2 \%$.

\section{ACKNOWLEDGMENT}

This research is funded by Kementerian Riset Teknologi and Pendidikan Tinggi via DRPM in year of 2018 (Skema Penelitian Dasar Unggulan Perguruan Tinggi).

\section{REFERENCES}

1. P. K. R. Nair, Agroforestry System in Tropics. Netherlands: Kluwer Academic Publishers, 1989.

2. D. N. Pandey, "Carbon sequestration in agroforestry systems", Climate policy, vol. 2, no. 4, pp. 367-377, 2002.

3. P. K. R. Nair and D. V. Nair, "Carbon Sequestration in Agroforestry System”, 2002. http://www.Idd.go.th./Wess2002/papers/0989.pdf. [ Acces 17 Maret 2005].

4. S. Brown, Guidelines for Inventory and Monitoring Carbon Offsets in Forest-Based Projects. Airlington: Winrock International, 1999.

5. Ministry of Environment Republic of Indonesia, National Strategy Study on DCM in Forestry Sector, Final Report, 2003.

6. J. Q. Chambers, J. Dos Santos, R. J. Ribeiro and N. Higuchi, "Tree damage, allometric relationships, and above-ground net primary production in central Amazon forest", Forest Ecology and Management, vol. 152, no. (1-3), pp. 73-84, 2001.

7. D. Zianis and M. Mencuccini, "On simplifying allometric analyses of forest biomass", Forest Ecology and Management. vol. 187, pp. 311-332, 2004. 
8. C. F. Cooper, "Carbon storage in managed forests." Canadian journal of forest research, vol. 13, no. 1, pp. 155-166, 1983.

9. Q. M. Ketterings, R. Coe, M. van Noordwijk and C. A. Palm. "Reducing uncertainty in the use of allometric biomass equations for predicting above-ground tree biomass in mixed secondary forests." Forest Ecology and management, vol. 146, no. (1-3), pp. 199-209, 2001

10. S. B. Tumwebaze, E. Bevilacqua, R. Briggs and T. Volk, "Allometric biomass equations for tree species used in agroforestry systems in Uganda." Agroforestry systems, vol. 87, no. 4, pp. 781-795, 2013.

11. W. B. Possu, J. R. Brandle, G. M. Domke, M. Schoeneberger and E. Blankenship, "Estimating carbon storage in windbreak trees on US agricultural lands." Agroforestry Systems, vol. 90, no. 5, pp. 889-904, 2016

12. S. Brown, Estimating biomass and biomass change of tropical forests: a primer. Rome: Food and Agriculture Org, 1977.

13. S. Brown, A. J. Gillespie and A. E. Lugo, "Biomass estimation methods for tropical forests with applications to forest inventory data", Forest science, vol. 35, no. 4, pp. 881-902, 1989.

14. K. G, MacDicken, A Guide to Monitoring Carbon Storage in Forestry and Agroforestry Projects. USA: Winrock International, 1977.

15. K. Hairiah, S. M. Sitompul, M. Van Noordwijk and C. Palm, Methods for sampling carbon stocks above and below ground . Bogor: ICRAF, 2001

16. Yohanes, A. R Langi, E. Suhendang and H. Poernomo, Model Penduga Biomassa dan Karbon Pohon Cempaka (Elmerillia Sp) dan Cempaka Wasian (Elmerillia Ovalis Sp) Pada Tegakan Hutan Rakyat di Kabupaten Minahasa. Magister Thesis, Institut Pertanian Bogor, 2007.

17. N. Draper and H. Smith, Applied Regression Analysis. New York: John Wiley and Sons, 1991

18. D. Zianis and M. Mencuccini. "On simplifying allometric analyses of forest biomass", Forest Ecology and Management. vol. 187, pp. 311-332, 2004.

19. S. Milena and K. Markku. "Allometrics Models for Tree Volume and Total Aboveground Biomass in A Tropical Humid Forest in Costa Rica." Biotropica, vol. 37, no. 1, pp. 2-8, 2005

20. J. C. Jenkins, D. C. Chojnacky, L. S. Heath and R. A. Birdsey. "National-scale biomass estimators for United States tree species", Forest science, vol. 49, no. 1, pp. 12-35, 2003. 